\title{
活性炭電極を用いた希薄水溶液からの 電解質の除去特性
}

\author{
三井宣志, 富田俊明, 小田廣和
}

(平成12年5月17日受理, 平成12年8月23日採択)

\section{Removal of Electrolytes from Dilute Aqueous Solutions Using Activated Carbon Electrodes}

\begin{abstract}
Nobuyuki Mitui, Toshiaki Tomita and Hirokazu Oda
The removal of electrolytes from aqueous solutions and cyclic operation were carried out using a small size flow through capacitor apparatus. The operation condition of the apparatus which are voltage, flow rates of solution and form of carbon electrode are determind. The effect of the characteristics of activated carbons on removal of various kinds of surfates electrolytes were discussed by using 9 kinds of activated carbons which were orginated from different raw materials. It is suggested that specific surface area of activated carbons contributed siginificantly to the removal of ions. Introduction of oxygen functional groups on the activated carbons promotes the amount of ion removal. It was recognized that it showed a tendency of removal as much as sulfates whose ion radius was small. In the case of cyclic operation, the electrodes are discharged or short-circuited at some point, adsorbed ions are desorped and the electrode is regenerated.
\end{abstract}

KEYWORDS : Carbon electrodes, Capacitor, Electrolytes, Pore-structure, Oxygen functional groups, Activated carbon

\section{1. 緒 言}

水溶液中からの微量無機化合物の除去に関しては, 電解法, 沈澱法やイオン交換法など種々の手法がある。これらの内で もイオン交換法は, 硬水の軟水化や純水の製造などに用いら れている一般的な手法である。しかしながら, 交換法におい ては定期的な再生操作が必要であり, 高分子樹脂の担体も反 復利用による劣化を伴うために時間的, 経済的に不利な面が 大きい。

活性炭は, 従来から物理吸着を主体とした水中の有機化合 物の吸着除去に広く用いられている。また, 活性炭による水 溶液中の微量重金属イオンの除去に関する研究も多く行われ ている。一方, 最近では, 炭素材料の導電性を利用して,これを 電極として用いて水中の金属イオンの除去を試みた研究が行 われている(1-4)。しかしこれらは，主に金属の種類が除去特性 に及ぼす影響を論じており, 炭素材電極の性状が, 除去の特性 におよぼす影響については,ほとんど考虑がなされていない。

そこで, 本報告では, 多孔性炭素材料の高い比表面積および 導電性を利用し, 水溶液中からの電解質の有効的な除去およ
び電極の再生方法の開発を目的とした。すなわち,電気二重 層キャパシ夕の概念を拡張し, 電解質溶液が流通できるよう にした通液型コンデンサ5)-7)を試作し，分極性電極に使用す る活性炭の性状や孔隙構造および表面の化学的特性が除去能 に及ほす寸影響について明らかにしようとした。また, 電極活 性炭の再生操作についても検討した。

\section{2. 実験方法}

\section{1 活性炭電極}

活性炭は, 市販の木質系活性炭2種類 $(\mathrm{AC}-1,2)$, 石炭系活 性炭（AC-3），楖子殼系活性炭（AC-4），フェノール系樹脂 (AC-5) およびピッチ系の高比表面積活性炭2種類（AC-6〜 9）の計9種を用いた。活性炭の表面官能基の影響を調べるた めに, AC-1については過酸化水素溶液中（10 - 30wt％) で液 相酸化し, 含酸素官能基を導入した。また, 官能基を除去する ために, 窒素雲囲気中 $800^{\circ} \mathrm{C} て ゙$ 熱処理を行った ${ }^{8)}$ 。表面官能基 の定量は, Boehmら9)の方法に準拠し, $\mathrm{NaOH}$ の消費量を測定 した。各活性炭について定容型吸着装置（島津-Micromeritics 社製ASAP2010）を用いて77Kに扔ける $\mathrm{N}_{2}$ の吸着等温線を求

関西大学工学部化学工学科：干564-8680 吹田市山手町3-3-35

Faculty of Engineering, Kansai University : 3-3-35 Yamate-cho, Suita 564-8680, Japan 
Table 1 Characteristics of activated carbons.

\begin{tabular}{c|c|c|c|c|c}
\hline Sample & $\begin{array}{c}\text { Surface Area* } \\
{\left[\mathrm{m}^{2} / \mathrm{g}\right]}\end{array}$ & $\begin{array}{c}\text { Pore Volume** } \\
{[\mathrm{ml} / \mathrm{g}]}\end{array}$ & $\begin{array}{c}\text { Acidity*** } \\
{[\mathrm{mmol} / \mathrm{g}-\mathrm{AC}]}\end{array}$ & $\begin{array}{c}\text { Ash } \\
{[\%]}\end{array}$ & Raw Material \\
\hline $\mathrm{AC}-1$ & 1300 & 0.53 & 0.817 & 0.49 & Charcoal \\
$\mathrm{AC}-2$ & 1000 & 0.34 & 0.551 & 0.51 & Charcoal \\
\hline $\mathrm{AC}-3$ & 1200 & 0.48 & 0.395 & 2.35 & Coal \\
$\mathrm{AC}-4$ & 1100 & 0.47 & 0.335 & 0.69 & Coconut-shell \\
\hline $\mathrm{AC}-5$ & 950 & 0.44 & 1.057 & 0.21 & Phenol-Resin \\
\hline AC-6 & 1800 & 0.80 & 1.473 & 0.25 & Pitch \\
AC-7 & 2300 & 1.02 & 1.613 & 0.24 & Pitch \\
AC-8 & 2600 & 1.24 & 1.656 & 0.24 & Pitch \\
AC-9 & 2900 & 1.34 & 2.402 & 0.22 & Pitch \\
\hline * B.E.T. procedure ** Cranston-Inkley procedure $* * *$ Boehm procedure
\end{tabular}

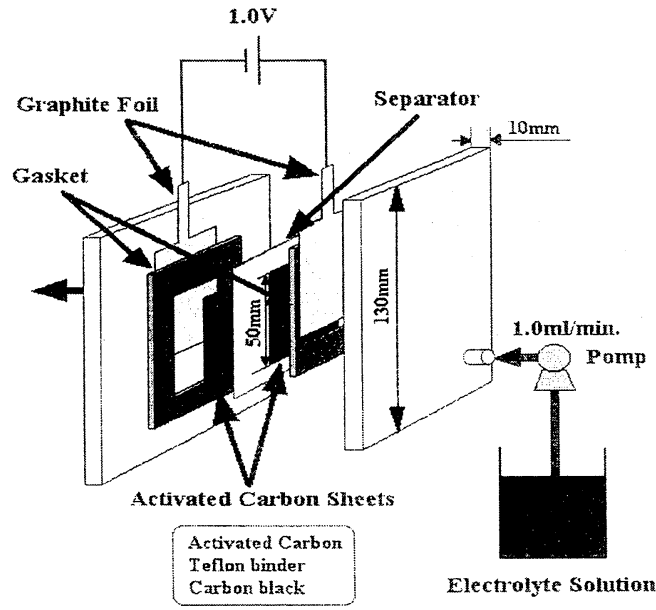

Fig.1 Apparatus of Flow Through Capacitor.

めた。これより比表面積はB.E.T.法, 細孔容積はCranstonInkley法を用いて解析を行い,その性状をTable 1に示した。

\section{2 除去装置}

Fig.1に示した構造の通液型コンデンサを試作した。活性 炭約 $2 \mathrm{~g}(45-75 \mu \mathrm{m})$ にカーボンブラックおよびテフロン樹脂

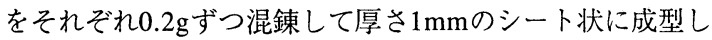
た。この背面に集電極のグラファイトシートを挟み込み, セ パレータを介して陽極, 陰極に分離した。この装置に電解質 溶液を定量ポンプで一定流速で通液し, 直流電圧を印加する ことにより除去を行った。

一方, 活性炭電極の再生操作は両極に逆電圧2Vを2分間印 加した後,さらに18分間短絡操作をして電極に捕集された電 解質を脱離させた。

\section{3 電解質}

電解質溶液は $\mathrm{Na}_{2} \mathrm{SO}_{4}, \mathrm{~K}_{2} \mathrm{SO}_{4}, \mathrm{CaSO}_{4}, \mathrm{Li}_{2} \mathrm{SO}_{4}, \mathrm{MgSO}_{4}, \mathrm{CaSO}_{4}$, $\mathrm{NiSO} 4, \mathrm{ZuSO}_{4}, \mathrm{CuSO}_{4}, \mathrm{MnSO}_{4}$ （市販特級品）の1.0mmol/1水 溶液を用いた。出口の電解質溶液濃度は, 予め作成した溶液 の濃度と電導度の関係の検量線より決定した。なお, 検量線

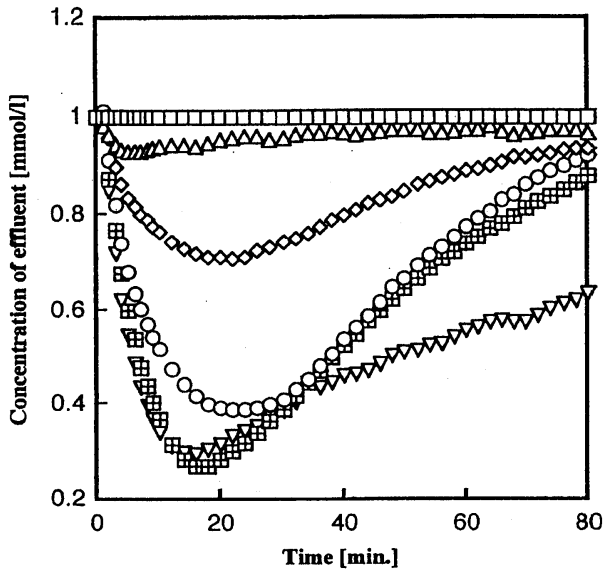

$\mathrm{Na}_{2} \mathrm{SO}_{4}: 1.0 \mathrm{mmol} / 1$, Flow rate $: 1.0 \mathrm{ml} / \mathrm{min}$. Activated carbon : AC-1

$\square: 0.00 \mathrm{~V}, \Delta: 0.25, \diamond: 0.50,0: 0.75$, 田: $1.00, \nabla: 1.25$

Fig.2 Influence of the applied voltage on ion removal.

の妥当性は原子吸光分析法も併用して評価した。

\section{3. 実験結果および考察}

\section{1 装置の特性}

電解質の除去について, 装置の最適運転条件を検討するた めに, 活性炭電極にAC-1, 除去の対象溶液として $\mathrm{Na}_{2} \mathrm{SO}_{4}$ を用 いた。この時, 電極に印加する電圧を $(0 \sim 1.25 \mathrm{~V})$, 電解質 の流速（1.0～2.5 ml/min.) を変化させ,それぞれの条件にお ける装置の除去特性を調べた。印加電圧が除去の特性に及ほ す影響について, 流速を $1.0 \mathrm{ml} / \mathrm{min}$.としてFig.2に示した。な お,ブランク試験として電圧を印加せずに電解質溶液のみを 通水したが, 電解質はまったく除去されなかったことを確認 した。印加電圧值を大きくするにつれて除去が急激に起こ り, 20分前後で最大となるがその後緩やかに減少する傾向が 見られる。これは電圧の上昇に対応して, 電極表面と水溶液 
中のイオンとの間に働く静電的引力が増すことによる。しか し, $1.25 \mathrm{~V}$ 以上を印加すると, 出口部の水溶液のpHに変動が生 じた。このことは,大気圧下における水の電気分解が1.23V付 近で起こるとされており，この影響によるものと考えられる。 したがって, 印加電圧を1.2V以下に設定して除去操作を行う ことにした。

Fig.3には, 電解質溶液の流速が除去能に及ぼす影響を示し た。低い流速ではセル内の電解質の滞留時間が長くなるの で, 大きな除去量が得られる。しかし, 流速を段階的に大きく すると除去量は,これに対応して減少した。このことは活性 炭表面と溶液との間に形成される境膜における拡散現象によ るものと思われる。そこで, 操作条件として最適と思われた 流速 $1.0 \mathrm{ml} / \mathrm{min}$. 標準に設定した。以上の結果より以後の実 験の運転条件を, 印加電圧 $1.0 \mathrm{~V}$, 電解質流速 $1.0 \mathrm{ml} / \mathrm{min}$. とし た。この条件におけるAC-1およびAC-6〜9を用いた $\mathrm{Na}_{2} \mathrm{SO}_{4}$ の除去率は, 前者で最大約 $40 \%$, 後者で約 $90 \%$ 以上を示した。

\section{2 活性炭電極の孔隙構造が除去特性に及ぼす影響}

電気二重層キャパシタにおいては, 一般に電極界面と電解 質溶液との界面に蓄積される容量は以下のように表される10)。

$$
\mathrm{C}=\int \varepsilon / 4 \delta \mathrm{d} S
$$

ここで, $\varepsilon は$ 電解質溶液の誘電率, $\delta$ は電極表面からイオン中 心までの距離, Sは電極界面の表面積である。すなわち, 同一 条件で操作した場合, 蓄積される容量は, 電極の表面積に依存 するとされている。電極に多孔性炭素を用いた場合, 除去に 有効な細孔構造を特定する必要があると思われる。そこで, Fig.4に80分間の活性炭単位重量当たりの累積除去量と, 各活
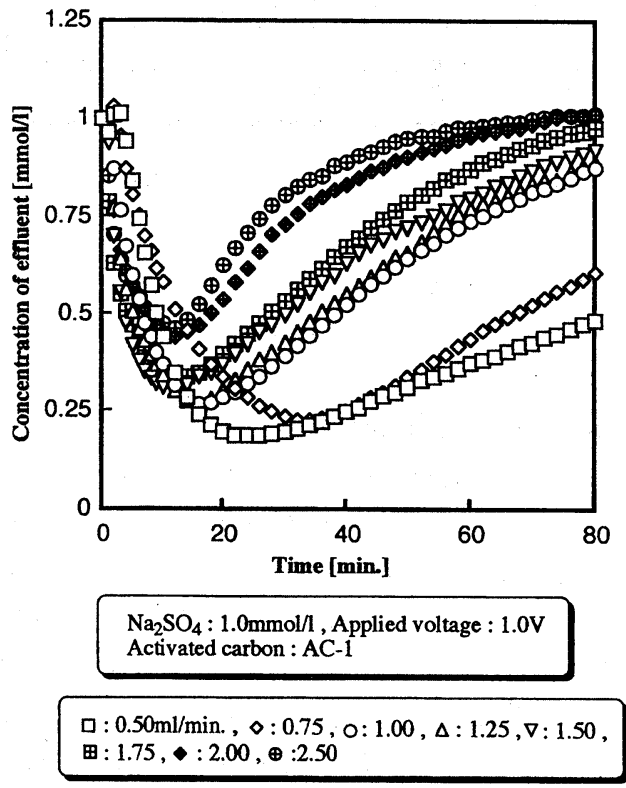

Fig.3 Effect of flow rate on the removal property. 性炭の比表面積（1-20nmの細孔径で構成されている構造） の関係を示した。本通液型コンデンサにおいても除去量は, おおむね活性炭の比表面積に依存 $\left(\mathrm{r}^{2}=0.920\right)$ した。特に同 一出発原料のAC-6〜9については, 極めて高い相関性 $\left(\mathrm{r}^{2}=\right.$ 0.995）があることがわかる。しかし, AC-3と4の両者につい ては,この傾向からの大きなずれが生じた。AC-3は石炭を原 料として製造された活性炭であり, 灰分が他の試料よりも多 いことによるものと予想された。そこで硝酸で脱灰した試料 を用いて検討を行ったが, 大きな変化は認められなかった。 一方, AC-4の原料は椰子殼であり, 灰分の含有は極めて少な いことから他の要因が関与しているものと思われる。このよ うに, 活性炭電極の電荷量は, 概ねその比表面積に依存する が, 表面官能基や原料に由来する炭素の微細結晶子構造の相 違なども複雑に影響を及ぼすものと思われる。

\section{3 電極の官能基が除去特性に及ぼす影響}

活性炭綫維電極を用いた電気二重層キャパシタにおいて, 表面酸素官能基が電気容量に影響をおよぼすことが指摘され ている"1)。Fig.5には, AC-1の表面官能基量を変化させた場合 の除去特性の変化を示した。酸性官能基の導入は, 初期段階 の除去速度を高める効果が認められる。一方, 官能基を熱分 解で減少させた活性炭から作製した電極では, 総除去量が小 さくなって明らかに除去能力が低下することが分かった。酸 化後の活性炭電極の静電電気容量を測定した結果, $10 \%$ 程大 きくなり酸性基量に対応して静電容量が増大する傾向があっ た。しかしながら,W.O.-20や30\%に見られるように過剩な 官能基の導入は, 総除去量を著しく低下させる。活性炭の酸 化処理に伴う細孔径約 1 ～10nmおよび約 $10 \sim 10^{5} \mathrm{~nm}$ の分布曲 線の変化をそれぞれFig.6に示した。官能基量の増大に伴っ

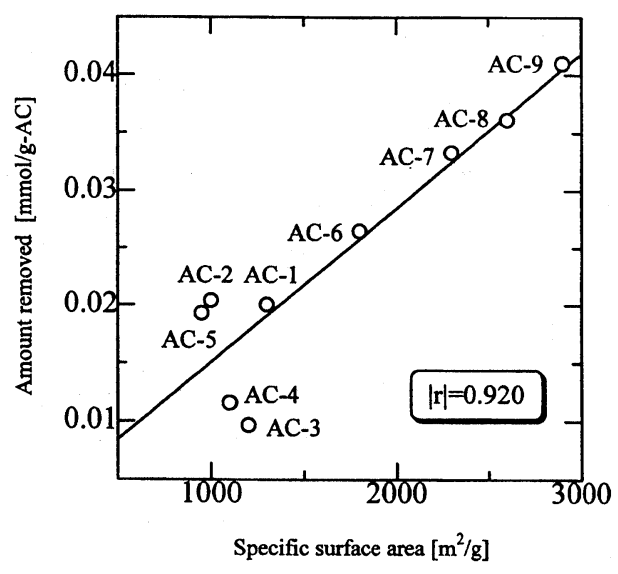

$\mathrm{Na}_{2} \mathrm{SO}_{4}: 1 \mathrm{mmol} / 1$, Flow rate $: 1.0 \mathrm{ml} / \mathrm{min}$. Applied voltage : $1.0 \mathrm{~V}$, Run time : $80 \mathrm{~min}$.

Fig.4 Relation between amount removed and specific surface area of activated carbons. 


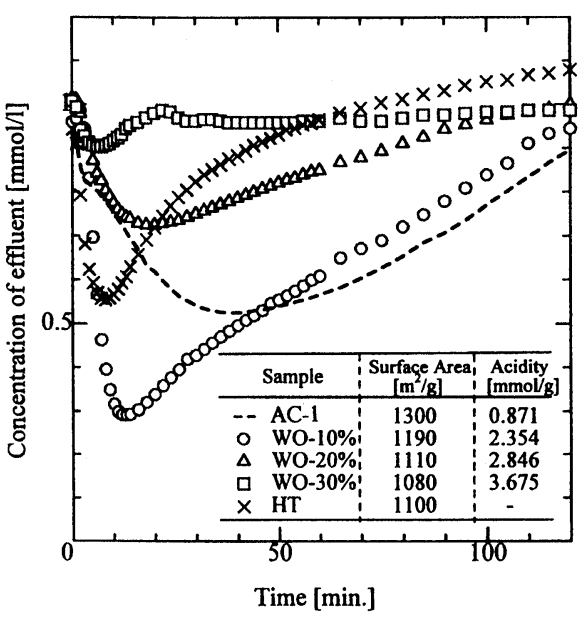

$\mathrm{Na}_{2} \mathrm{SO}_{4}: 1 \mathrm{mmol} / 1$, Used activated carbon : AC-1 Flow rate $: 1.0 \mathrm{ml} / \mathrm{min}$. , Applied voltage $: 1.0 \mathrm{~V}$

Fig.5 Change of removal properties of various kinds of oxidized AC-electrodes.
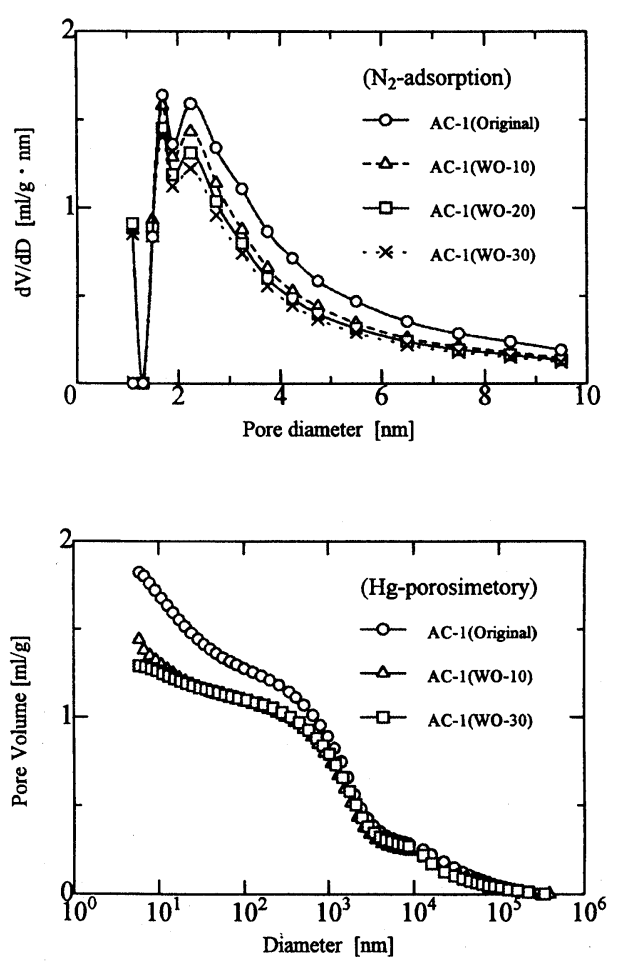

Fig.6 Pore size distribution curves of oxidized activated carbons.

て, 細孔が減少する傾向にあるが, 分布の形態に大きな恋化は 認められない。また, 官能基の導入によって比表面積が小さ く評価されることはすでに知られてる8)。ここに見られる除 去量の減少は, 比較的大きな細孔の入り口に生成した官能基 により,電解質の細孔内への移動が妨害されるためと思われ

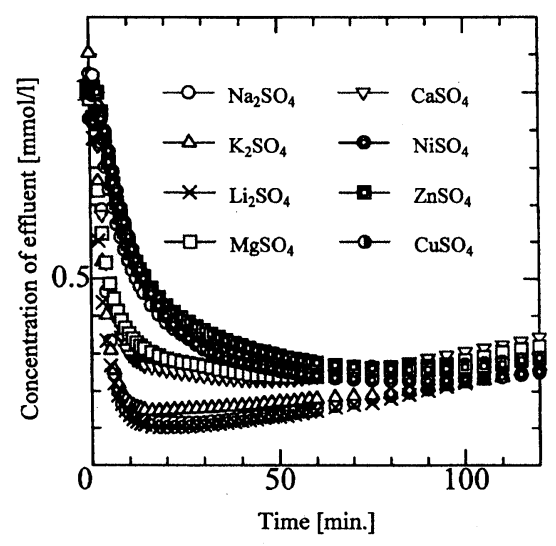

Flow rate : $1.0 \mathrm{ml} / \mathrm{min}$. , Concentration : $1 \mathrm{mmol} / 1$ Applied voltage : $1.0 \mathrm{~V}$, Used activated carbon : AC-8

Fig.7 Removal properties of AC-8 for some sulfates.

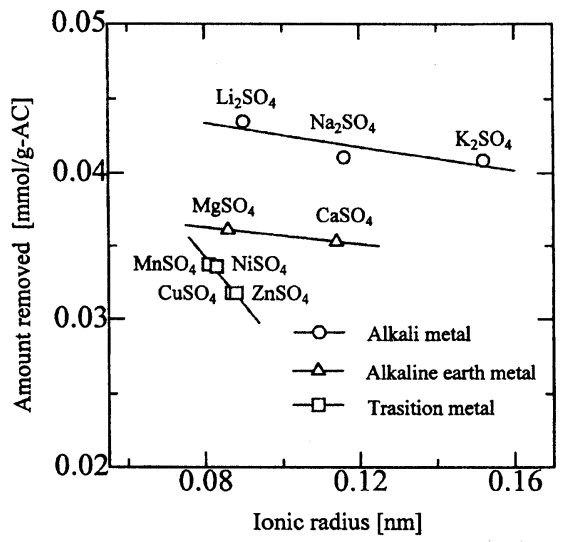

Flow rate : $1.0 \mathrm{ml} / \mathrm{min}$, Used Activated Carbon : AC-8 Applied voltage : $1.0 \mathrm{~V}$, Run time : $120 \mathrm{~min}$.

Fig.8 Relation between amount removed and ionic radius.

る。したがって, 初期に見られる除去速度の向上は, 主に官能 基による親水性の改善と官能基の帯電の増加によるものと考 えられる。

\section{4 各種硫酸塩の除去特性}

Fig.7に活性炭電極AC-8を用いて, 8種類の硫酸塩電解質を 処理した場合の除去率の経時変化を示した。いずれの1価イ オンも除去されやすい傾向にあるが, 中でもLiイオンが顕著 である。同じ傾向はSeronらによっても指摘されている。水 溶液中のLiイオンに対して, 電圧を印加すると炭素表面の含 酸素官能基が解離し, イオン種と官能基の間で, ある種のイオ ン交換的な反応が起こることを示唆されている12)。1価イオ ンに比べて2価イオンでは, 初期除去速度および除去量が小さ い。特にZn, NiおよびCuでは, 除去初期の段階からこの傾向 


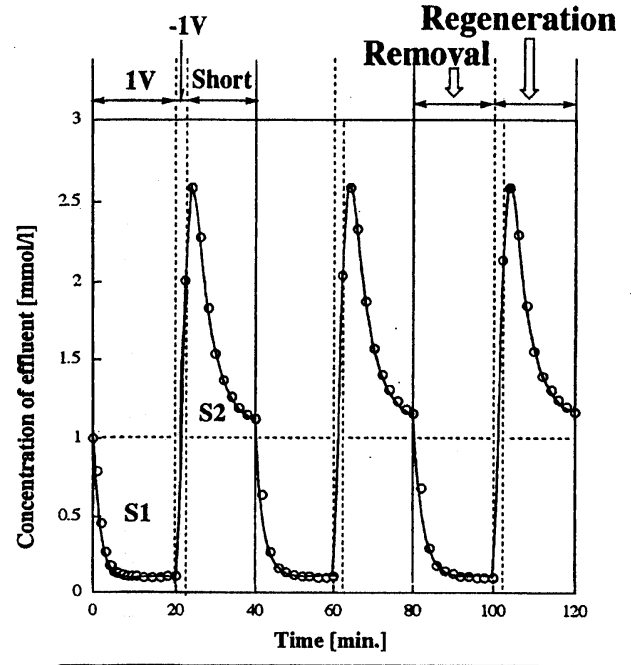

$\mathrm{Na}_{2} \mathrm{SO}_{4}: 1.0 \mathrm{mmol} / 1$, Flow rate $: 1.0 \mathrm{ml} / \mathrm{min}$. Applied voltage : $1.0 \mathrm{~V}$, Activated Cabon : AC-8

Fig.9 Cyclic operation of FTC.

が見られる。これらのイオンはイオン化傾向が小さく, 比較 的に還元されやすい。そのために，電極表面で還元され金属 として析出後, 細孔の閉塞を引き起こすために除去量が少な くなったものと考えられる。先に示したように電極活性炭の 比表面積と除去量の間に相関的な関係があることからFig.8 に各塩のイオン半径と120分間の累積総除去量との関係を整 理して示した。塩の種類は少ないので定性的な表現になる が,イオン半径が小さい金属イオンほど, 吸着されやすい傾向 が伺える。これらのことから, 混合溶液中に還元されやすい イオンが共存する多成分系の除去操作では, 活性炭の細孔の 入り口付近へのイオンの析出を防止する工夫が必要である。 例えば, 還元されやすいイオンを予馀去するか, 印加電圧を 低く設定することなどが考えられる。

\section{4 再生操作}

電極の再生利用を目的として, $\mathrm{AC}-8$ を用いて $\mathrm{Na}_{2} \mathrm{SO}_{4}$ の除去 を行なった後, 逆電圧を 2 分間, 短絡を 18 分間操作した時の出 口濃度の経持変化をFig.9に示した。除去量と脱着量を比較す ると,ほほ等しいことから, 電気二重層の形成で除去された電 解質は, この脱離操作で容易に排出されたものと判断される。 再生時間の短縮は, 逆電圧 $2 \mathrm{~V}$ を印加することによって, 大幅に 短縮できるが電気分解および電極の酸化が生じる。なお, 50 サイクル程度の繰り返し操作では, 電極の大きな劣化は認め られなかった。今後，長期に渡る反覆利用に対する評価およ び再生時間の短縮等について, さらに検討する必要がある。

\section{4. 結 言}

通液型コンデンサを用いることにより, 希薄な水溶液から
低電圧で電解質を除去することが可能であり, 多孔性炭素電 極を選択することにより，最大 $90 \%$ 以上の除去率を得ること ができた。除去量はおおむね活性炭の比表面積に依存し，除 去に有効な細孔は約1 3 $3 \mathrm{~nm}$ 付近の径の部位であると推測さ れた。また, 活性炭の表面官能基は, 電解質の除去を増進させ る効果があるが, 最適な量があると思われる。イオン半径の 小さい電解質ほど, 除去されやすい傾向が認められた。多孔 性電極の細孔径を制御することにより，ある種の選択的除去 が期待できると思われる。しかしながら，除去量が活性炭の 孔隙構造のみにより，一義的に決定されるものではない事も 明らかになった。活性炭の有する表面化学特性や結晶構造な ど, 除去に影響を与えると思われる要因が複数あるため,さら に多角的な観点より考察する必要があると思われる。また， 装置の再生操作は, 逆電圧を印加する操作で行うことが可能 であり, 再生操作による除去能の低下は極めて小さいことが 分かった。

\section{謝 辞}

本研究の一部は平成9 11年度文部省科学研究費補助金重 点領域「カーボンアロイ」研究および関西大学ハイテクリサ 一チ・センターの補助金によって行ったものである。関西熱 化学株式会社の音羽利郎博士に試料の提供, ご助言を頂いた。 ここに深く感謝の意を表します。

\section{文 献}

1) M. Ichinose, T. Yasuoka, S. Mitsuzawa and T. Sasaki, Bull. Chem. Soc. Jpn. 59 (1986) 3347-3349.

2) G.G. Jayson, J.A. Sangster, G. Thompson and M.C.Wilkinson, Carbon 25 (1987) 523-531.

3) G.G. Jayson, J.A. Sangster and M.C. Wilkinson, Carbon 31 (1993) 487-492.

4) J. Rivera-Utrilla, M.A. Ferro-Garía, M.D. Mingorance and I. Bautista-Toledo, J. Chem.Tech. Biotechnol. 36 (1986) 36-47.

5) T. Otowa, US Patent 5 (1996) 538, 611.

6) T. Otowa, T. Tomita, H. Oda and M.D. Andelman, Proc. Sixth. Int. Conf. Fundamentals of Adsorption (1998) 945950, Elsevier.

7) H. Oda, N. Mitui and T. Tomita, International Symposium of Carbon, Extended Abstracts, Tokyo, 1998, 492-493.

8) H. Oda, T. Nishimoto and T. Kishima, TANSO 1997 [No.176] 20-25 [in Japanese].

9) H. P. Boehm, E. Diehl, W. Heck and R. Sappok, Adv. in Catalysis 16 (1966) 179-274.

10) A. Nishino, TANSO 1988 [No.132] 57-71 [in Japanese].

11) A. Yoshida, I. Tanahashi and A. Nishino, Carbon 28 (1990) 611-615.

12) A. Seron, H. Benaddi, F. Beguin, E. Fackowiak, J.L. Bretelle, M.C. Thiry, T.J. Bandosz, J. Jagiello and J.A. Schwarz, Carbon 34 (1996) 481-487. 